\title{
LARGE ANEURYSM OF BASILAR ARTERY TIP MIMICKING MIDBRAIN TUMOR AND CAUSING UNILATERAL OBSTRUCTIVE HYDROCEPHALUS: A CASE REPORT AND TECHNICAL NOTE
}

\author{
Vladimir Kalousek ${ }^{1}$, Bruno Splavski ${ }^{2,3,4}$, Vili Beroš2, ${ }^{2,}$ Branimir Čulo ${ }^{1}$, Filip Vrban², \\ Ante Rotim ${ }^{6}$ and Krešimir Rotim $2,3,7$
}

${ }^{1}$ Department of Radiology, Sestre milosrdnice University Hospital Centre, Zagreb, Croatia; ${ }^{2}$ Department of Neurosurgery, Sestre milosrdnice University Hospital Centre, Zagreb, Croatia; 3Josip Juraj Strossmayer University of Osijek, Faculty of Medicine, Osijek, Croatia; ${ }^{4}$ Josip Juraj Strossmayer University of Osijek, School of Dental Medicine and Health, Osijek, Croatia; ${ }^{5}$ Ministry of Health, Republic of Croatia, Zagreb, Croatia; ${ }^{6}$ Department of Neurosurgery, Dubrava University Hospital, Zagreb, Croatia; University of Applied Health Sciences, Zagreb, Croatia

\begin{abstract}
SUMMARY - Cerebral ventricular system is a sporadic location of intracranial aneurysms including those of basilar artery tip. Treatment of such aneurysms remains challenging regardless of endovascular or microsurgical techniques applied. Basilar tip aneurysm presenting as third ventricular mass is rarely associated with obstructive hydrocephalus, mimicking midbrain expansive process and urging precise diagnostics and prompt treatment. Hence, the management of such patients may be delicate, having an uncertain outcome. We report on a case of a patient with unilateral hydrocephalus caused by large basilar tip aneurysm mimicking a midbrain tumor. We also discuss different operative strategies influencing the outcome, including our own endovascular treatment technical modification. A 62-year-old female patient presented with slightly decreased cognition, minor gait disturbances and urinary incontinence. Computed brain tomography revealed a third ventricle mass with unilateral ventricular dilatation, indicating hypertensive obstructive hydrocephalus. Magnetic resonance and digital subtraction angiography identified the third ventricular mass as a large saccular basilar tip aneurysm. The patient was selected for endovascular treatment followed by cerebrospinal fluid derivation. After aneurysm endovascular occlusion and temporary external ventricular drainage, the symptoms diminished and ventricular dilatation decreased. On post-procedure day 10, the hydrocephalus was relieved and external drainage removed. The patient recovered fully and was discharged without neurological deficit. In conclusion, large basilar tip aneurysms associated with obstructive hydrocephalus are rare and best treated by a combination of endovascular obliteration and cerebrospinal fluid ventricular diversion. The possibility of such an aneurysm should always be considered on the differential diagnosis of cerebral ventricular growths.
\end{abstract}

Key words: Basilar tip aneurysm; Obstructive hydrocephalus; Endovascular treatment; Ventricular drainage

\section{Introduction}

Cerebral ventricular system is a rare location of intracranial aneurysms. Most ventricular aneurysms arise from a distal branch of choroidal arteries and ma-
Correspondence to: Prof. Bruno Splarski, $M D, P h D$, Department of Neurosurgery, Sestre milosrdnice University Hospital Centre, Vinogradska c. 29, HR-10000 Zagreb, Croatia

E-mail: splavuno@gmail.com

Received February 17, 2020, accepted March 14, 2020 
jor branches of the circle of Willis ${ }^{1}$, including basilar artery (BA). Treatment of basilar apex aneurysms, which constitute $5 \%-8 \%$ of all intracranial aneurysms, remains challenging and demanding regardless of endovascular or microsurgical techniques applied ${ }^{2}$.

Basilar artery tip aneurysms presenting as third ventricular masses are most uncommon ${ }^{3,4}$, and they are rarely associated with obstructive hydrocephalus. However, when there is such an association, the rise of intracranial pressure (ICP) is always present, mimicking midbrain expansive process and commending precise diagnostics and urgent treatment. Under this con-

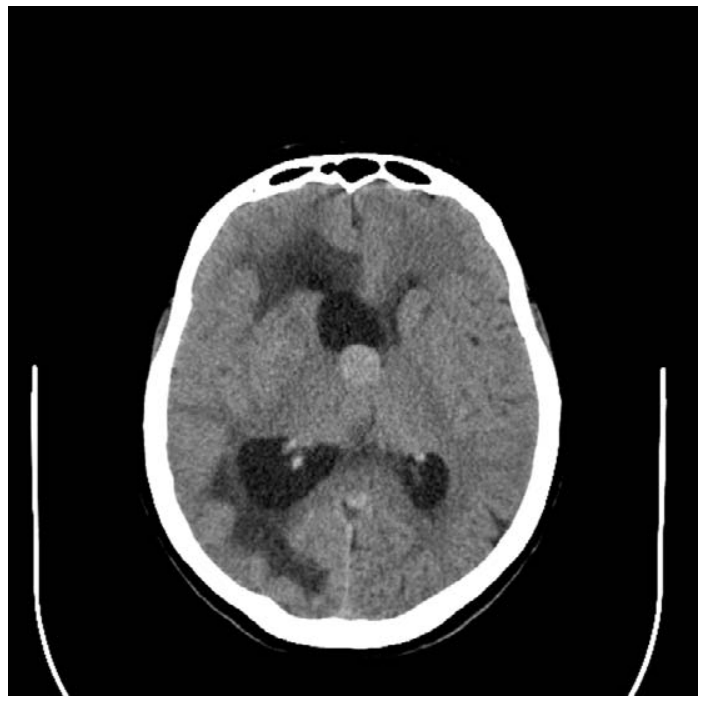

Fig. 1. Axial computed tomography of the brain revealing a hyperdense expansive solid mass in the third ventricle with one-sided dilatation of the right lateral ventricle and periventricular effusion. dition, reducing intracranial hypertension by ventricular shunting may produce further aneurysmal growth and even increase the threat of aneurysmal rupture ${ }^{5}$. Therefore, the management of such patients may be delicate, having an uncertain outcome.

Hereby, we report on a case of a female patient with right-sided unilateral obstructive hypertensive hydrocephalus produced by a non-ruptured, partly thrombosed large BA tip aneurysm with a compressive effect on the third ventricle floor, foramen of Monro, and mesencephalic structures, mimicking a midbrain tumor. We also provide a technical note on our own modified endovascular procedure and discuss different operative techniques available, which may influence outcomes to the great extent.

\section{Case Report}

A 62-year-old female patient presented with slightly decreased cognitive skills. Besides minor gait disturbances and partial urinary incontinence, no major motor weakness or other neurological deficit was found at hospital admission.

Native and contrast-enhanced axial computed tomography $(\mathrm{CT})$ of the brain revealed a hyperdense solid expansive mass at the foramen of Monro of the third ventricle with one-sided dilatation of the right lateral ventricle and periventricular effusion, indicating a hypertensive obstructive unilateral hydrocephalus (Fig. 1). Magnetic resonance angiography (MRA) and supra-selective digital subtraction angiography (DSA) of the cerebral vessels identified the third
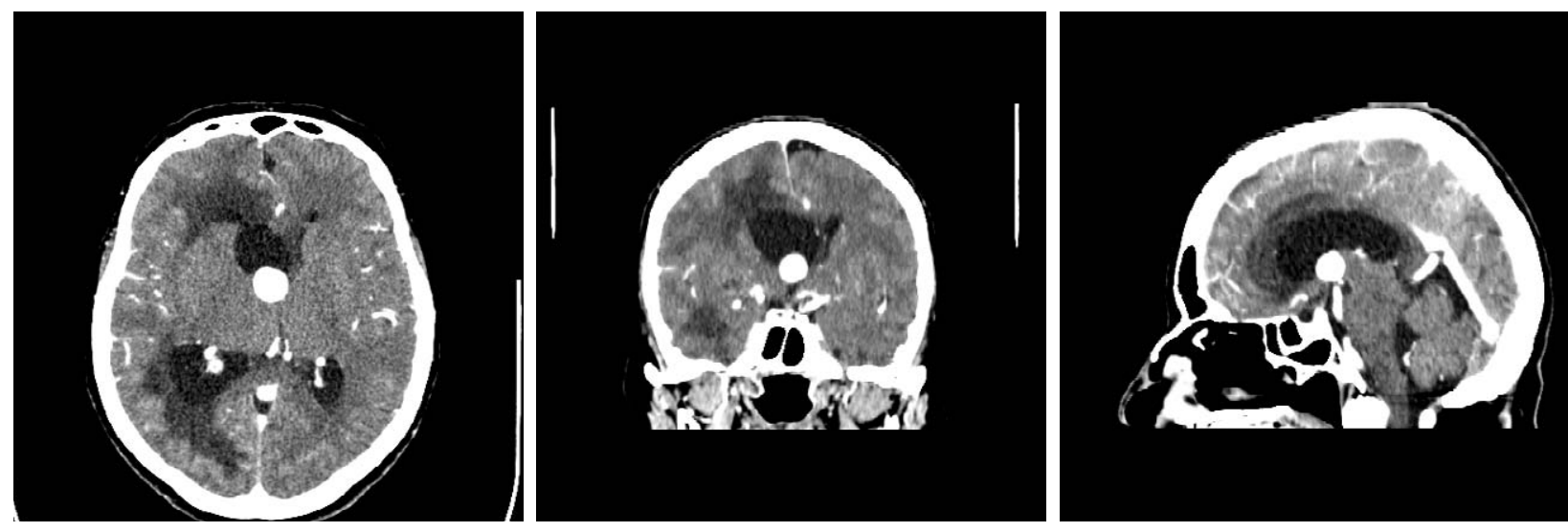

Fig. 2. Magnetic resonance angiography of the cerebral vessels in axial (a), coronal (b), and sagittal reformations (c), identifying the third ventricular mass lesion as a large saccular basilar tip aneurysm measuring $17 \mathrm{~mm}$ in diameter. 

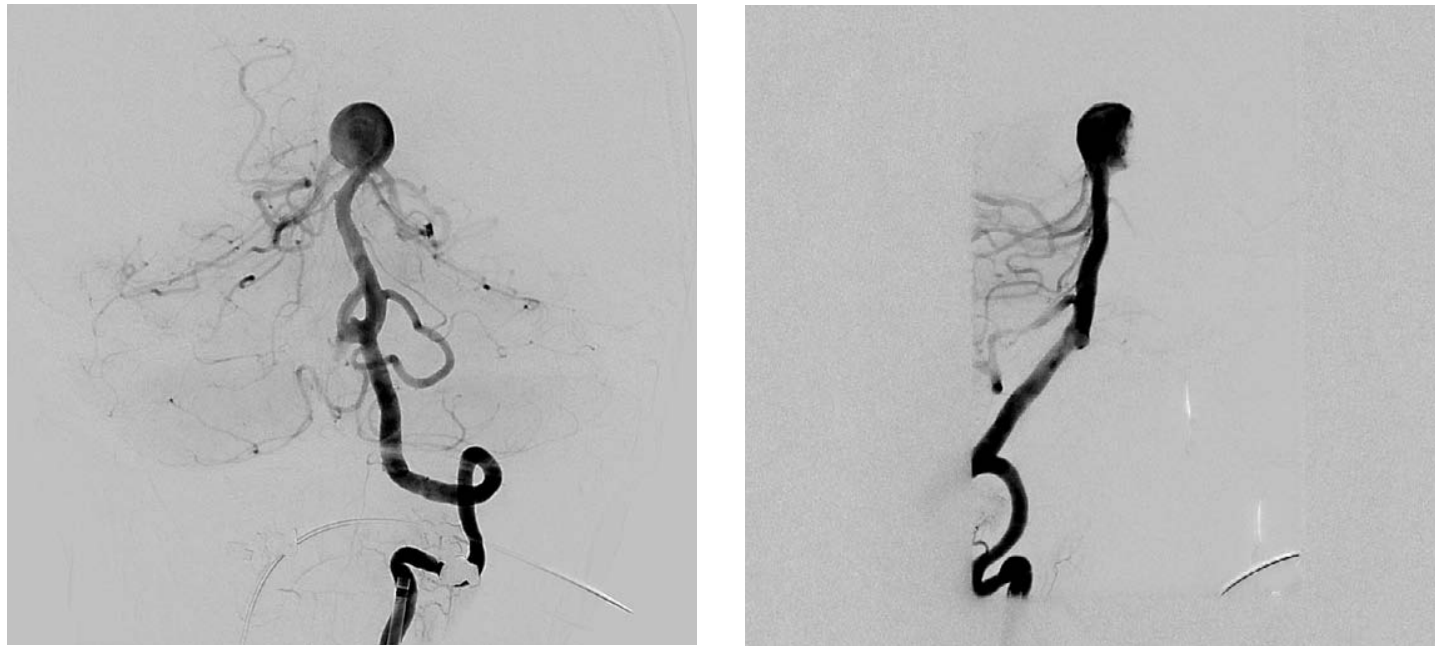

Fig. 3. Supra-selective cerebral digital subtraction angiography in anterior-posterior (a), and latero-lateral projection (b), depicting a large saccular aneurysm of basilar artery apex with partially thrombosed fundus.

ventricular mass lesion as a large saccular basilar tip aneurysm measuring $17 \mathrm{~mm}$ in diameter (Fig. 2a-c; Fig. 3a,b).

The patient was selected for endovascular treatment followed by cerebrospinal fluid (CSF) derivation. After aneurysm coil occlusion and temporary external ventricular drainage (EVD), the symptoms immediately diminished and ventricular dilatation decreased (Fig. 4; Fig. 5a,b; Fig. 6). A modification of the 'gold' standard in the treatment of wide-neck aneurysms with balloon remodeling (firstly described by Moret $e t$ al. in 1997) was applied ${ }^{6}$. This relatively novel technique for protecting/remodeling the aneurysm neck and preserving both posterior cerebral arteries (PCA) consists of Y-Comaneci/balloon configuration, which narrows the effective neck and straightens the vascular bifurcation angle ${ }^{7,8}$. Similar technique but with double Comaneci device was described by Sirakov et al. in $2018^{9}$. A balloon catheter was placed in P1 segment of the right PCA, while a Comaneci bridging device was positioned in P1 segment of the left PCA, thus ensuring both $\mathrm{P} 1$ segments to stay open and at least one cerebellar hemisphere to remain constantly/sufficiently blood-supplied, since both the posterior communicating arteries (PComs) were lacking (Fig. 4). Then, a microcatheter was placed in the aneurysmal sac, which was packed with 15 coils (Fig. 5a,b). No additional devices (stents/flow diverters) were used to avoid the need for double antiplatelet therapy.

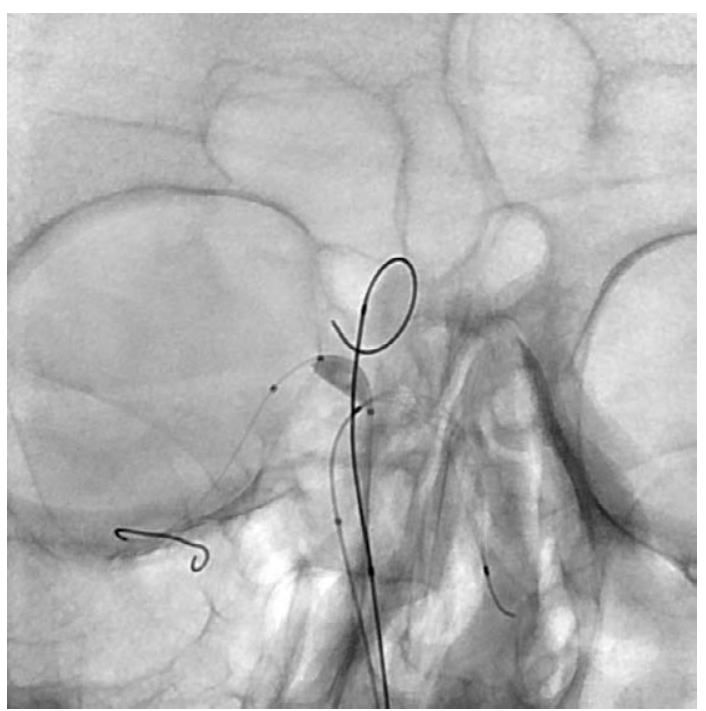

Fig. 4. Cerebral digital subtraction angiography in anterior-posterior projection depicting a balloon scepter XC catheter placed into $P 1$ segment of the right posterior cerebral artery (PCA) and Comaneci bridging device placed into P1 segment of the left PCA, together with microcatheter in the aneurysmal sac.

Native brain axial dynamic CT scanning performed immediately after the endovascular procedure confirmed correctly placed external ventricular catheter in the frontal horn of the right lateral ventricle, away from the coiled BA aneurysm fundus (Fig. 6). Follow-up CT brain scanning performed on day 10 

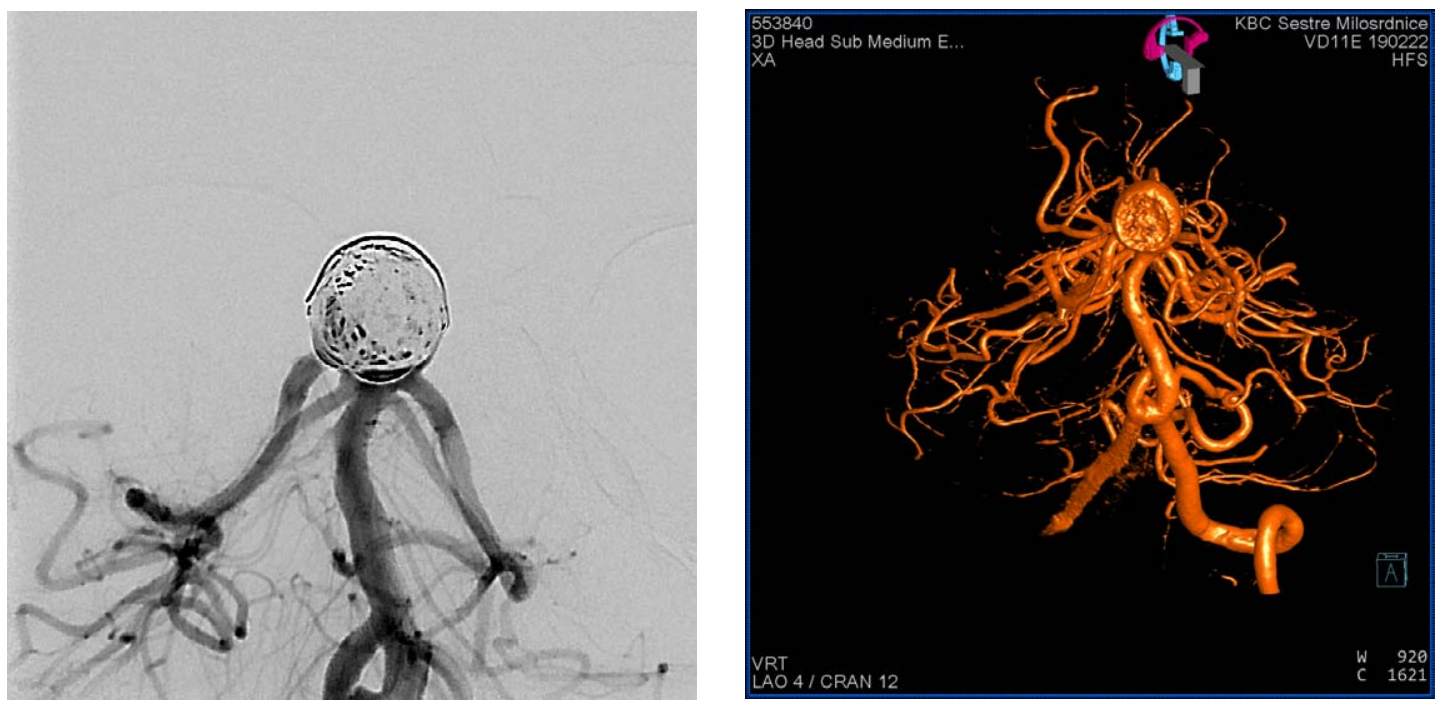

Fig. 5. Supra-selective cerebral digital subtraction angiography (a), and 3D angiography (b) after endovascular occlusion of the aneurysm sac packed with 15 coils and supported by Y-Comaneci/balloon configuration.

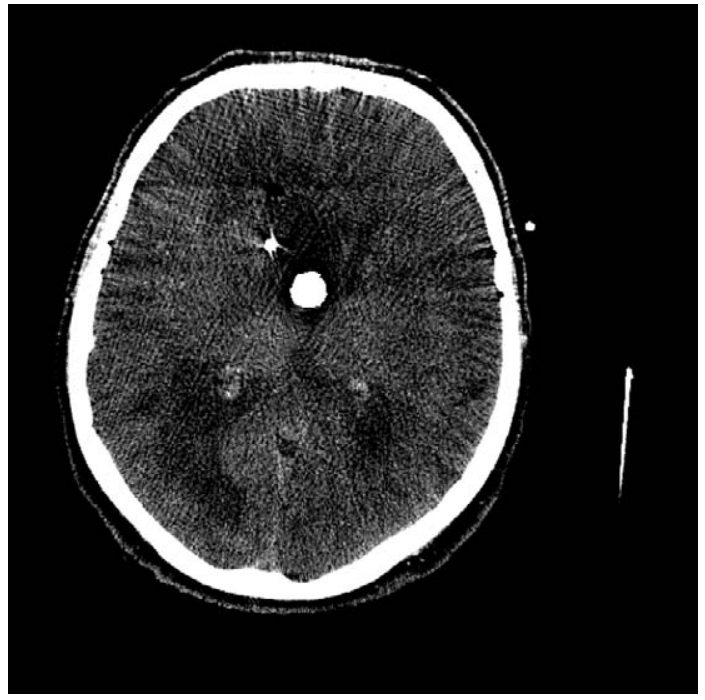

Fig. 6. Dynamic brain axial computed tomography performed immediately after the endovascular procedure, confirming correctly placed external ventricular catheter away from the coiled basilar artery aneurysm fundus.

post-procedure confirmed the retrieving dynamics of hydrocephalus with noticeably decreased ventricular dilatation and periventricular effusion (Fig. 7).

Regular CSF specimens were obtained to check CSF parameters of possible intrathecal infection, which were all negative. On day 10 following the pro-

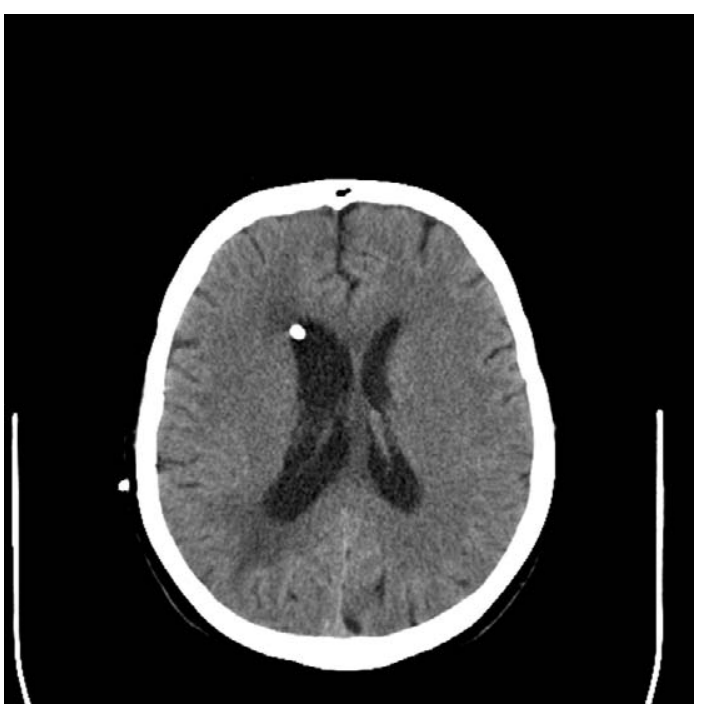

Fig. 7. Native axial brain computed tomography performed 10 days post-procedure showing correctly placed catheter in the frontal horn of the right lateral ventricle and retrieving dynamics of hydrocephalus with markedly decreased ventricular dilatation and periventricular effusion, as well as slightly present midline shifting in the recovery phase.

cedure, the EVD was removed. Afterwards, the patient recovered fairly and was discharged without any neurological deficit. A meticulous clinical and radiological follow-up with brain CT scanning and MRA at one 
month was advised to monitor ventricular dimensions and possible aneurysm recurrence, in which case the additional stenting/flow diverting would be needed.

\section{Discussion}

Posterior circulation aneurysms account for $10 \%-$ $20 \%$ of all intracranial aneurysms. The most common site of origin for such aneurysms is the basilar tip, followed by the posterior inferior cerebellar artery (PICA $)^{10,11}$. Basilar apex aneurysms constitute 5\%-8\% of all intracranial aneurysms, and their treatment remains challenging for both microsurgical and endovascular approaches ${ }^{2}$, due to their demanding location and specific morphology. Since they are frequently wide-necked, endovascular stent-assisted coiling or balloon remodeling are often required ${ }^{6,12}$.

The literature concerned with development of obstructive hydrocephalus caused by giant/large BA tip aneurysm is scarce and only a few case report/small case series have been described so far ${ }^{3-5,13-16}$. The clinical and radiological signs, as well as the differential diagnostic considerations have been addressed ${ }^{13,16}$. However, there was no universal management option for this rare and delicate condition proposed. The selection of various treatment strategies was mainly aimed at aneurysm obliteration and CSF derivation to decrease ICP and to relieve the mass effect. These different strategies, including external temporary ventriculostomy, ventriculo-peritoneal (V-P) shunting, or endoscopic third ventriculostomy (ETV), together with aneurysm clipping or coiling ${ }^{17-20}$, have brought diverse outcomes that were not always favorable. Considering this, it seems that EVT is a safe and effective alternative to $\mathrm{V}-\mathrm{P}$ shunting in selected patients ${ }^{17-19}$, particularly in cases where a sufficient space for the surgical procedure is present in the prepontine cis$\operatorname{tern}^{19}$. Simultaneously, direct microsurgical clipping of most BA apex aneurysms can be performed with acceptable rates of morbidity in high-volume and wellequipped centers ${ }^{2,10,21}$. However, endovascular treatment has taken a larger role in the management of BA tip aneurysms $\mathrm{s}^{2,20}$, where coil embolization, as well as flow disruption and stenting remain optimal techniques. Yet, the difficulties in obtaining complete and stable endovascular occlusion are still present, particularly for wide-neck aneurysms with complex geometry ${ }^{22}$. Nonetheless, patients with BA apex aneurysms are more likely to be treated by endovascular management, but they have higher recurrence rates when compared with those treated microsurgically ${ }^{21}$. Because of that, Y-configuration balloon-assisted stent coiling, and different bridging expedients, such as the Comaneci device, are advised to induce cerebrovascular remodeling, preserve bilateral PCAs, ensure adequate cerebellar blood supply, and support aneurysm coiling occlusion ${ }^{6-9,22-24}$.

Having in mind all the above and the specific clinical condition of our patient requiring rapid decisionmaking, we opted for temporary EVD preceded by endovascular aneurysm coiling supported by balloon catheterization and aneurysm neck bridging. Finally, we removed the EVD when hydrocephalus was relieved. Such a treatment strategy brought a favorable short-term outcome for our patient.

In conclusion, giant/large basilar tip aneurysm associated with obstructive hydrocephalus is a rare condition that is best treated by a combination of aneurysm endovascular coil obliteration and CSF diversion due to its complex geometry and underlying pathology. The possibility of such BA aneurysm should always be considered on the differential diagnosis of third ventricular growths producing a mass effect. Ventricular CSF drainage is a prerequisite for further successful treatment and satisfactory outcome. A broad armamentarium of different endovascular techniques including balloon and stent-assisted coiling and neck bridging for this wide-neck aneurysm occlusion is on disposal now.

Obviously, further extensive reading and systematic review of the literature are necessary to support our conclusion.

\section{References}

1. Sanli AM, Cekirge S, Sekerci Z. Aneurysm of the distal anterior cerebral artery radiologically mimicking a ventricular mass. J Neurosurg. 2011;114(4):1061-4. doi: 10.3171/2010.6.JNS 10370.

2. Tjahjadi M, Serrone J, Hernesniemi J. Should we still consider clips for basilar apex aneurysms? A critical appraisal of the literature. Surg Neurol Int. 2018;9:44. doi: 10.4103/sni.sni_ 311_17.

3. Bose B, Northrup B, Osterholm J. Giant basilar artery aneurysm presenting as a third ventricular tumor. Neurosurgery. 1983;13 (6):699-702. doi: 10.1227/00006123-198312000-00016. 
4. Liu JK, Gottfried ON, Couldwell WT. Thrombosed basilar apex aneurysm presenting as a third ventricular mass and hydrocephalus. Acta Neurochir (Wien). 2005;147(4):413-6. doi: 10.1007/s00701-004-0452-8.

5. Hongo K, Morota N, Watabe T, Isobe M, Nakagawa H. Giant basilar bifurcation aneurysm presenting as a third ventricular mass with unilateral obstructive hydrocephalus: case report. J Clin Neurosci. 2001;8(1):51-4. doi: 10.1054/jocn.2000.0730.

6. Moret J, Cognard C, Weill A, Castaings L, Rey A. Reconstruction technique in the treatment of wide-neck intracranial aneurysms. Long-term angiographic and clinical results. A propos of 56 cases. J Neuroradiol. 1997;24:30-44.

7. Akgul E, Aksungur E, Balli T, Onan B, Yilmaz DM, S. Bicakci $\mathrm{S}$, et al. Y-stent-assisted coil embolization of wide-neck intracranial aneurysms. A single center experience. Interv Neuroradiol. 2011;17:36-48. doi: 10.1177/159101991101700107.

8. Sağlam M, Kızılkılıç O, Anagnostakou V, Yıldız B, Koçer N, Işlak C. Geometrical characteristics after Y-stenting of the basilar bifurcation. Diagn Interv Radiol.2015;21(6):483-7. doi: 10.5152/dir.2015.14523.

9. Sirakov SS, Sirakov A, Hristov H, Raychev R. Coiling of ruptured, wide-necked basilar tip aneurysm using double Comaneci technique. BMJ Case Rep. 2018;2018:bcr2017222703. doi: 10.1136/bcr-2017-222703.

10. Redekop GJ, Durity FA, Woodhurst WB. Management-related morbidity in unselected aneurysms of the upper basilar artery. J Neurosurg. 1997;87:836-42. doi:10.3171/jns.1997.87. 6.0836 .

11. Sugita K, Kobayashi S, Takemae T, Tada T, Tanaka Y. Aneurysms of the basilar trunk. J Neurosurg. 1987;66:500-5.

12. Marlin ES, Ikeda DS, Shaw A, Powers CJ, Sauvageau E. Endovascular treatment of basilar aneurysms. Neurosurg Clin North Am. 2014;25(3):485-95. doi: 10.1016/j.nec.2014.04.007.

13. Goetz C, Seifert V, Haubitz B. The foramen of Monro blockage caused by a giant aneurysm of the basilar artery. A case report and review of the literature. Neurochirurgia (Stuttg). 1990;33(4):122-6. doi: 10.1055/s-2008-1053570.

14. Piek J, Lim DP, Bock WJ. Obstructive hydrocephalus caused by a growing, giant aneurysm on the upper basilar artery. Surg Neurol. 1983;20(4):288-90. doi: 10.1016/0090-3019(83) 90080-0.
15. Rozario RA, Levine HL, Scott RM. Obstructive hydrocephalus secondary to an ectatic basilar artery. Surg Neurol. 1978;9 (1):31-4.

16. Tsutsumi S, Kondo A, Abe Y, Yasumoto Y, Ito M. Basilar apex aneurysm manifesting as third ventricular mass and obstructive hydrocephalus - case report. Neurol Med Chir (Tokyo). 2008; 48(10):451-4. doi: 10.2176/nmc.48.451.

17. Obaid S, Weil AG, Bojanowski MW. Endoscopic third ventriculostomy in the presence of large or giant basilar artery aneurysms. Acta Neurochir (Wien). 2012;154(10):1845-50. doi: 10.1007/s00701-012-1461-7.

18. Oertel JMK, Mondorf Y, Gaab MR. Endoscopic third ventriculostomy in obstructive hydrocephalus due to giant basilar artery aneurysm. J Neurosurg. 2009;110(1):14-8. doi: 10.3171 /2008.7.JNS0887.

19. Sato M, Nakai Y, Takigawa T, Takano S, Matsumura A. Endoscopic third ventriculostomy for obstructive hydrocephalus caused by a large upper basilar artery aneurysm after coil embolization. Neurol Med Chir (Tokyo). 2012;52(11):832-4. doi: 10.2176/nmc.52.832.

20. Watanabe A, Imamura K, Ishii R. Endosaccular aneurysm occlusion with Guglielmi detachable coils for obstructive hydrocephalus caused by a large basilar tip aneurysm. Case report. J Neurosurg.1999;91(4):675-8.doi:10.3171/jns.1999.91.4.0675.

21. Bohnstedt BN, Ziemba-Davis M, Sethia R, Payner TD, DeNardo A, Scott J, et al. Comparison of endovascular and microsurgical management of 208 basilar apex aneurysms. J Neurosurg. 2017;127(6):1342-52. doi: 10.3171/2016.8.JNS16703.

22. Sirakov SS, Sirakov A, Hristov H, Minkin K, Penkov M, Karakostov V. Early experience with a temporary bridging device (Comaneci) in the endovascular treatment of ruptured wide neck aneurysms. J Neurinterv Surg. 2018;10(10):978-82. doi: org/10.1136/neurintsurg-2017-013641.

23. Gao B, Baharoglu MI, Cohen AD, Malek AM. Y-stent coiling of basilar bifurcation aneurysms induces a dynamic angular vascular remodeling with alteration of the apical wall shear stress pattern. Neurosurgery. 2013;72(4):617-29. doi: 10.1227/ NEU.0b013e3182846d9f.

24. Miyachi S, Matsubara N, Izumi T, Asai T, Yamanouchi T, Ota $\mathrm{K}$, et al. Stent/balloon combination assist technique for widenecked basilar terminal aneurysms. Interv Neuroradiol. 2013; 19(3):299-305. doi: 10.1177/159101991301900306. 
Sažetak

\title{
VELIKA ANEURIZMA VRŠKA BAZILARNE ARTERIJE PREDSTAVLJENA KAO MEZENCEFALIČNI TUMOR I UZROK JEDNOSTRANOG OPSTRUKCIJSKOG HIDROCEFALUSA: PRIKAZ SLUČAJA I TEHNIČKA NAPOMENA
}

\author{
V. Kalousek, B. Splavski, V. Beroš, B. Čulo, F. Vrban, A. Rotim i K. Rotim
}

Intrakranijske su aneurizme smještene unutar ventrikulskog sustava rijetke, uključujući one vrška bazilarne arterije. Njihovo je liječenje izrazito zahtjevno, neovisno o primijenjenoj endovaskularnoj ili mikrokirurškoj tehnici. Aneurizme bazilarnoga vrška koje se očituju kao ventrikulska ekspanzivna tvorba u području mezencefalona rijetko su povezane s razvitkom opstrukcijskoga hidrocefalusa, što zahtijeva preciznu dijagnostiku i žurno aktivno liječenje. Postupak je liječenja u ovakvih bolesnika iznimno složen, a ishod neizvjestan. U ovom radu opisujemo slučaj bolesnice s jednostranim hidrocefalusom uzrokovanim velikom aneurizmom bazilarnoga vrška, koja se diferencijalno dijagnostički očitovala kao mezencefalični tumor. Također raspravljamo o različitim mogućnostima operacijskog liječenja od utjecaja na ishod, uključujući i vlastitu tehničku modifikaciju endovaskularnog zahvata. Bolesnica u dobi od 62 godine zaprimljena je zbog blago sniženih kognitivnih sposobnosti, manjeg poremećaja u hodu i urinarne inkontinencije. Kompjutorska tomografija mozga upućivala je na ekspanzivnu tvorbu područja treće klijetke s jednostranim proširenjem postranične klijetke i posljedičnim hipertenzivnim hidrocefalusom. Magnetna rezonancija i digitalna suptrakcijska angiografija razotkrile su ekspanzivnu tvorbu kao veliku sakularnu aneurizmu bazilarnoga vrška. Bolesnica je podvrgnuta endovaskularnom liječenju sa susljednom derivacijom cerebrospinalnoga likvora. Simptomi i proširenje postranične klijetke su se umanjili nakon učinjene endovaskularne okluzije i privremene izvanjske ventrikulske drenaže. Desetog dana od operacije hidrocefalus se u cijelosti povukao pa je izvanjska drenaža uklonjena. Bolesnica se je u potpunosti oporavila te je otpuštena bez neurološkog ispada. Zaključujemo kako su aneurizme bazilarnoga vrška udružene s opstrukcijskim hidrocefalusom rijetke i kako ih je najpovoljnije liječiti kombinacijom endovaskularnog postupka i likvorske ventrikulske derivacije. Na mogućnost nastanka ovakve aneurizme treba uvijek pomisliti u diferencijalnoj dijagnostici cerebralnih ventrikulskih tvorba.

Ključne riječi: Aneurizma bazilarnoga vrška; Opstrukcijski hidrocefalus; Endovaskularni postupak; Ventrikulska drenaža 